Volume 1 Nomor 2 Edisi Desember 2013
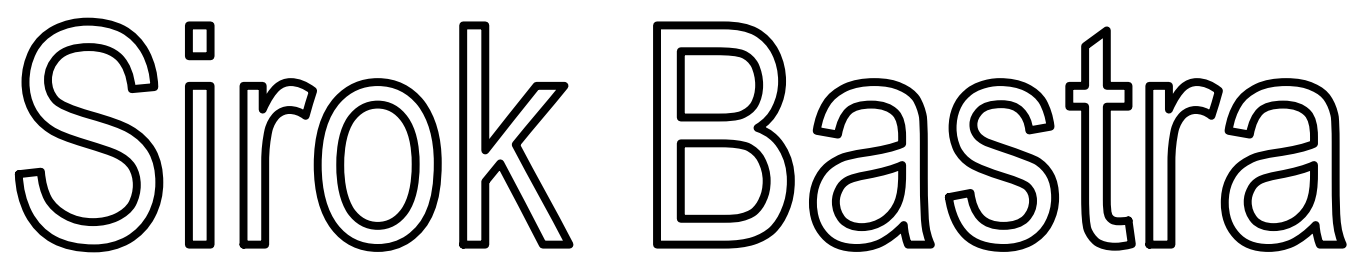

J URNAL ILMIAH KEBAHASAAN DAN KESASTRAAN

\begin{tabular}{|c|c|c|c|c|c|}
\hline $\begin{array}{c}\text { Sirok Bastra } \\
\text { Jurnal Kebahasaan dan } \\
\text { Kesastraan }\end{array}$ & Volume 1 & Nomor 2 & $\begin{array}{c}\text { Hlm. } \\
123-249\end{array}$ & $\begin{array}{c}\text { Pangkalpinang, } \\
\text { Desember } \\
2013\end{array}$ & $\begin{array}{c}\text { ISSN } \\
2354-7200\end{array}$ \\
\hline
\end{tabular}

KANTOR BAHASA KEPULAUAN BANGKA BELITUNG 

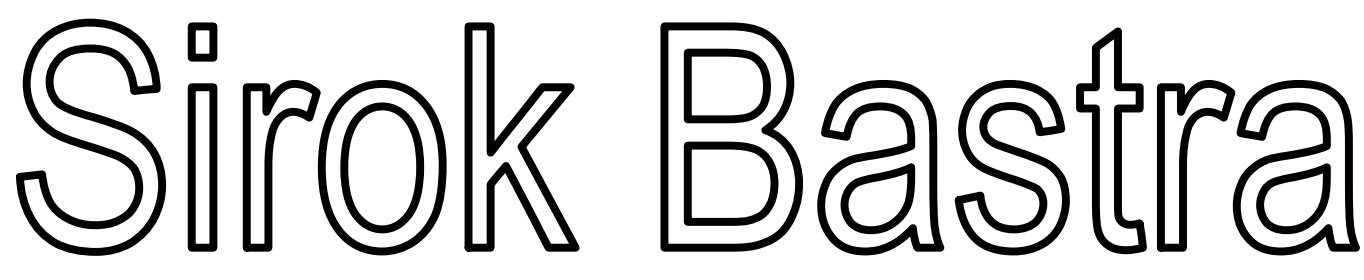

\section{J URNAL ILMIAH KEBAHASAAN DAN KESASTRAAN}

Jurnal ini merupakan wadah informasi mengenai kebahasan, kesastraan, dan pengajarannya yang memuat hasil penelitian, studi kepustakaan, dan tulisan ilmiah bidang kebahasan, kesastraan, dan pengajarannya. Jurnal ini terbit dua kali setahun, yakni Juni dan Desember, serta terbit sejak Juni 2013.

\section{Penanggung Jawab}

Kepala Kantor Bahasa Provinsi Bangka Belitung

Drs. Umar Solikhan, M.Hum.

\section{Mitra Bestari}

Prof. Dr. Agus Nuryatin, M.Hum. (Bidang Bahasa dan Pengajarannya)

Prof. Amrin Saragih, Ph.D., M.A. (Bidang Sastra dan Pengajarannya)

Dr. Felicia Nuradi Utorodewo, M.Hum. (Bidang Bahasa dan Pengajarannya)

Dr. Pujiharto, M.Hum. (Bidang Sastra dan Pengajarannya)

\section{Pemimpin Redaksi}

Rahmat Muhidin, S.S.

\section{Penyunting}

Prima Hariyanto, S.Hum.

\section{Perancang Sampul}

Feri Pristiawan, S.S.

\section{Kesekretariatan}

Khaliffitriansyah, S.Pd. Dea Letriana Cesaria, S.Hum.

Lia Aprilina, S.Pd.

Andrian Priyatno, A.Md.

Elzam

\section{Alamat Redaksi dan Penerbit}

Kantor Bahasa Provinsi Bangka Belitung

Ruko Permata 7, Jalan Solihin G.P. Km 4, Pangkalpinang, Kep. Bangka Belitung

Telp./Faks.: 0717-438455, Pos-el: sirokbastra@gmail.com

Pemuatan suatu tulisan dalam jurnal ini tidak berarti redaksi menyetujui isi tulisan tersebut. Isi tulisan menjadi tanggung jawab penulis. Tulisan telah ditinjau oleh mitra bestari. Setiap karangan dalam jurnal ini dapat diperbanyak setelah mendapat izin tertulis dari penulis, redaksi, dan penerbit. 


\section{KATA PENGANTAR}

Puji syukur ke hadirat Pemilik dan Pencipta semesta ini yang memiliki kuasa atas diri-Nya sendiri. Dialah Tuhan Yang Maha Esa yang telah memberikan rahmat dan hidayah-Nya sehingga Volume 1 Nomor 2 Jurnal Sirok Bastra dapat terbit tepat pada waktunya.

Pada nomor kedua ini, dimuat sebelas tulisan, yakni enam tulisan kebahasaan, empat kesastraan, dan satu pengajaran sastra. Dari segi bahasa, sebagian besar tulisan disajikan dalam bahasa Indonesia, hanya dua tulisan yang disajikan dalam bahasa Inggris. Kami mengucapkan terima kasih kepada para penulis yang telah bersedia menerbitkan karya mereka pada edisi ini. Para penulis merupakan para peneliti, pakar, dosen, dan mahasiswa dari berbagai perguruan tinggi dan instansi. Terima kasih juga kami sampaikan kepada para mitra bestari kami yang telah memberi ulasan terhadap tulisan-tulisan yang masuk ke redaksi.

Demi memenuhi keberagaman isi dan penulis, Sirok Bastra membuka kesempatan bagi para peneliti dan penulis menyampaikan hasil penelitian dan pemikiran mutakhir dalam bidang kebahasaan, kesastraan, dan pengajarannya.

Pangkalpinang, Desember 2013

Tim Redaksi 


\section{UCAPAN TERIMA KASIH UNTUK MITRA BESTARI}

Redaksi Sirok Bastra mengucapkan terima kasih kepada para mitra bestari yang telah meninjau, menimbang, dan mengulas makalah-makalah yang diterbitkan dalam Sirok Bastra Volume 1 Nomor 2, edisi Desember 2013, yakni

Prof. Dr. Agus Nuryatin, M.Hum.

Bidang Sastra dan Pengajarannya

Universitas Negeri Semarang

Semarang, Jawa Tengah

Prof. Amrin Saragih, Ph.D., M.A.

Bidang Bahasa dan Pengajarannya

Universitas Negeri Medan

Medan, Sumatra Utara

Dr. Felicia Nuradi Utorodewo, M.Hum.

Bidang Bahasa dan Pengajarannya

Universitas Indonesia

Depok, Jawa Barat

\section{Dr. Pujiharto, M.Hum.}

Bidang Sastra dan Pengajarannya

Universitas Gadjah Mada

Yogyakarta, Daerah Istimewa Yogyakarta 


\section{DAFTAR ISI}



UCAPAN TERIMA KASIH UNTUK MITRA BESTARI .................................................... ii



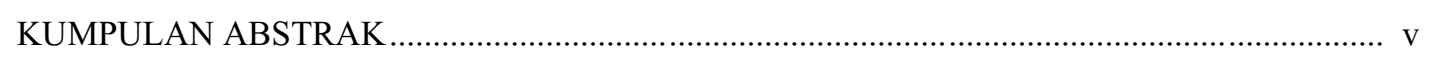

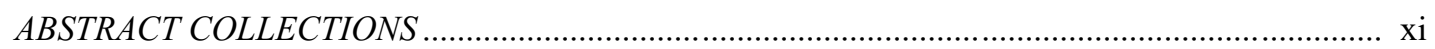

BAHASA INDONESIA DALAM INFORMASI DAN IKLAN DI RUANG PUBLIK KOTA PANGKALPINANG

(Indonesian in Information and Advertising in Public Space Pangkalpinang)

Umar Solikhan $123-129$

PERBEDAAN MAKNA NOMINA BERAFIKS $P E-, P E R-, P E--A N$, DAN $P E R--A N$ DALAM NASKAH HIKAYAT BAYAN BUDIMAN, HIKAYAT MUHAMMAD HANAFIYYAH, DAN HIKAYAT RAJA PASAI

(Affixed Noun Meaning Differences of pe-, per-, pe--an, and per--an in The Hikayat Bayan Budiman, Hikayat Muhammad Hanafiyyah, and Hikayat Raja Pasai Manuscripts)

Rindias H. Fatmasari $131-147$

WACANA RUBRIK INTIMATE DI MAJALAH DIGITAL INTERAKTIF MALE

(Intimate Rubric in Male Digital Interactive Magazine Discourse)

Prima Hariyanto $149-160$

AN ACOUSTICAL CONTRASTIVE ANALYSIS OF SUNDANESE CENTRAL VOWELS (Analisis Konstrastif Akustik Vokal Pusat Bahasa Sunda)

Yusup Irawan. $161-175$

KATA SUDAH SEBAGAI PENANDA ASPEK DENGAN AWALAN TER-

The Word of Sudah as An Aspect with Prefix Ter-

Dea Letriana Cesaria $177-182$

PERUBAHAN DAN PERGESERAN MAKNA DALAM KATA-KATA BERDERIVASI NOMINA KE VERBA YANG MENGANDUNG AFIKS $M E(N)-, M E(N)-K A N$, DAN $M E(N)-I$ PADA SURAT KABAR HARIAN KOMPAS

(Change and Shift of Meaning in The Derivated Words Nomine to Verb That Contain Affixes $m e(N)-$, me(N)-kan, dan me(N)- $i$ in The Kompas The Daily Newspaper)

Teodora Nirmala Fau $183-193$

MENCIPTA-KREATIF NASKAH DRAMA DENGAN STRATEGI MENULIS TERBIMBING (Creative Writing of Playscript eith Guided Writing Strategy)

Sony Sukmawan. $195-205$ 
PENGARUH KONSEP HAGABEON, HAMORAON, DAN HASANGAPON TERHADAP

KETIDAKSETARAAN GENDER DALAM AMANG PARSINUAN

(The Influence of Hagabeon, Hamoraon, and Hasangapon Concept for Gender Inequality in Amang Parsinuan)

Fransiska Simangunsong $207-220$

PERSPEKTIF PENGARANG MENGENAI RELASI ANTARA MANUSIA DAN

LINGKUNGAN HIDUP DALAM NOVEL PARTIKEL KARYA DEWI LESTARI: SEBUAH KAJIAN EKOKRITISISME

(Author's Perspective on The Relationship Between Humans and The Environment in The Novel Partikel Written by Dewi Lestari: an Ecocriticism Studies)

Alfi Yusrina Ramadhani $221-229$

FENOMENA HUKUM ADAT BALI TERHADAP BAYI KEMBAR BUNCING DALAM

NOVEL INCEST KARYA I WAYAN ARTIKA

Bali Custom Law Phenomenon of Kembar Buncing Infant in I Wayan Artika Novel Incest Annisa Aprinandri Irwin dan Khansa Khairunnisa $231-241$

RELIGIOUS AND MORAL VALUES IN MADURA FOLKTALES

Religiositas dan Nilai Moral dalam Cerita-Cerita Rakyat Madura

Imron Wakhid Harits. $243-249$ 
Annisa Aprinandri ... : Fenomena Hukum Adat Bali terhadap Bayi Kembar ...

\title{
FENOMENA HUKUM ADAT BALI TERHADAP BAYI KEMBAR BUNCING DALAM NOVEL INCEST KARYA I WAYAN ARTIKA
}

\author{
Bali Custom Law Phenomenon of Kembar Buncing Infant in I Wayan Artika Novel Incest \\ Annisa Aprinandri Irwin dan Khansa Khairunnisa \\ Nurul Fikri Boarding School \\ Kampung Cihideung, Desa Bantar Waru, Cinangka, Serang, Banten \\ pos-el: aprinandri.irwin@gmail.com
}

(diterima 30 Mei 2013, disetujui 30 September 2013, revisi terakhir 24 Oktober 2013)

\begin{abstract}
Abstrak
Artikel ini memaparkan bentuk fenomena adat Bali tentang kembar buncing dalam novel Incest karya I Wayan Artika. Metode yang digunakan dalam penelitian adalah kualitatif dan analisis dalam menyimpulkan data. Berdasarkan analisis, disimpulkan bahwa peristiwa inses dalam Kembar Buncing ini dilakukan masyarakat Bali tanpa mengetahui akibatnya. Semua dilakukan mengatasnamakan adat istiadat yang sudah ada sejak zaman dahulu. Dalam pandangan adat Jelungkap, sanksi untuk kembar buncing di Bali adalah suatu hal yang lumrah dan wajib dilaksanakan. Ada tiga tahapan hukuman dalam kebudayaan kembar buncing, pertama diisolasi, kedua melakukan upacara malik sumpah, dan yang terakhir adalah pemisahan bayi buncing dari pasangannya. Budaya kembar buncing ini sangat bertentangan dengan Hak Asasi Manusia karena setiap manusia berhak mendapat hak hidup yang sama.
\end{abstract}

Kata kunci: Incest, kembar buncing, Bali, budaya, tradisi

\begin{abstract}
This paper describes the phenomenon of Balinese traditional form of kembar buncing in I Wayan Artika novel Incest. The method used in the study was qualitative and analysis in summing up the data. Based on the analysis, it was concluded that the incest events in the Twin Buncing is done without knowing the consequences. All done on behalf of customs that have existed since long time ago. In the traditional view of Jelungkap, penalty for twin buncing in Bali is a common thing and must be implemented. There are three stages of penalty in the kembar buncing culture, first isolation, second perform malik sumpah ceremony, and the last is buncing infant separation from her partner. Kembar buncing culture is quite contradict to the Human Rights because every human being entitled to the same right to life.
\end{abstract}

Kata kunci: Incest, kembar buncing, Bali, culture, tradition

\section{PENDAHULUAN}

\subsection{Latar Belakang}

Karya sastra lahir karena adanya imajinasi yang diolah dengan ide pikiran dan perasaan seorang pengarang. Pada dasarnya, karya sastra untuk dinikmati karena karya sastra (terutama cerpen, novel, dan drama) dapat menjadi potret kehidupan melalui tokoh-tokoh ceritanya. Karya sastra merupakan tulisan yang bernilai estetik serta bersifat imajinatif atau fiktif, yakni berangkat dari daya khayal kreatif. Teks sastra merupakan karya yang amat kompleks karena sastra menggambarkan kehidupan manusia dengan berbagai macam dimensi yang ada. Oleh karena itu, untuk mempelajari teks sastra secara sistematik, penelaah sastra tidak saja dituntut untuk menguasai teori sastra, melainkan juga disiplin ilmu yang lain, seperti filsafat, sosiologi, psikologi, agama, politik dan sebagainya. (Fananie, dalam Hariyanto, 2010).

Karya sastra yang dibuat dengan kesungguhan tentu mengandung keterikatan yang kuat dengan kehidupan karena manusia pencipta karya sastra tersebut merupakan bagian dari kehidupan itu sendiri. Sastra sebagai produk kehidupan mengandung nilainilai sosial, filosofi, religi dan sebagainya. Stanton (dalam Hariyanto, 2010) menjelaskan bahwa fiksi adalah kehidupan, sedangkan kehidupan adalah permainan yang paling menarik. Membaca fiksi yang 
bagus ibarat memainkan permainan yang tinggi tingkat kesulitannya dan bukan seperti memainkan permainan sepele tempat para pemain menggampangkan atau bahkan mengabaikan peraturan yang ada.

Karya sastra merupakan hasil cipta atau karya yang bersifat imajinatif. Sebagai hasil imajinasi, sastra berfungsi sebagai bahan bacaan yang menyenangkan. Di dalamnya, sarat dengan nilai-nilai budaya dan berguna menambah kekayaan batin bagi permasalahan manusia, kemanusiaan, dan kehidupan (Nurgiyantoro, dalam Hariyanto, 2009). Karya sastra pada dasarnya untuk dinikmati karena karya sastra (terutama cerpen, novel dan drama) dapat menjadi potret kehidupan melalui tokoh-tokoh ceritanya yang kompleks dan sarat konflik.

Karya sastra merupakan potret kehidupan masyarakat. Karena banyaknya fenomena yang terjadi di masyarakat tentang hubungan seksual sedarah (inses), peneliti tertarik untuk membahas novel berjudul Incest yang bercerita tentang sepasang anak kembar, laki-laki dan perempuan yang dikenal dengan istilah kembar buncing. Bali merupakan daerah yang memiliki ragam budaya. Hingga zaman yang sudah modern seperti sekarang ini, beberapa tradisi yang dianggap sakral masih tetap dilestarikan. Hal ini kerap menjadikan kesan bahwa masyarkat Bali itu begitu kaku dan diskriminatif. (Ratnasari, dalam Hariyanto, 2009).

Kebudayaan Bali sebagai salah satu bagian dari kebudayaan Indonesia sesungguhnya dapat dilihat sebagai suatu hasil dan sekaligus proses penghayatan terhadap nilai-nilai luhur yang telah disepakati bersama sebagai dasar pijakan oleh para pendukungnya. Dengan demikian, kebudayaan Bali pada awalnya adalah landasan perilaku yang khusus dimaksudkan untuk memenuhi kebutuhan masyarakat Bali sendiri. Namun, ketika kebudayaan Bali ditempatkan ke dalam tatanan kebudayaan Indonesia, usaha-usaha untuk mengembangkan kebudayaan harus diarahkan kepada tatanan yang bersifat nasional. (Majong, dalam http://melayuonline.com).

Sesuai aturan adat yang berlaku di bali pada masa, jika sepasang suami istri melahirkan sepasang buncing, orangtua si kembar buncing tersebut harus mengalami penyucian dengan cara diisolasi selama empat puluh dua hari di muara desa atau dekat kuburan (yang di dalam novel disebut langking langkau). Setelah melakukan pengisolasian dilakukanlah upacara malik sumpah (upacara atau ritual yang harus dilaksanakan oleh keluarga yang melahirkan buncing). Kemudian bagian terberat adalah memisahkan bayi buncing mereka. Setelah itu, pada saat dewasa dan siap menikah nanti, mereka harus dinikahkan dengan saudara kembarnya. Lontar Dewa Tatwa dan Brahma Tatwa yang menyebutkan bahwa kelahiran buncing adalah manusia yang lahir dengan ketidakwajaran. Incest adalah sebuah novel karya sastra karangan I Wayan Artika, novel ini pertama kali diterbitkan sebagai cerita bersambung dalam berita harian lokal, Bali Post tahun 2003. Pada bulan Desember, Artika dipanggil oleh tetua desa tempat ia tinggal dan disidang. Artika divonis telah menjelek-jelekkan adat istiadat dan juga budaya Bali yang mereka junjung tinggi melalui cerita karangannya. Menurut masyarakat Bali, budaya inses dalam istiadat kembar buncing ini adalah suatu hal yang suci dan juga mulia. Dengan alasan itulah I Wayan Artika, pengarang novel Incest harus menerima hukum adat, beliau harus dibuang dari desa tempat ia lahir dan juga tinggal. Bulan itu pula, Incest dihentikan peredarannya. Pada tahun 2008 Pinus Publishing akhirnya membukukan Incest karya I Wayan Artika ini.

Menurut Dirgantara dalam webkemal.blogspot.com, inses merupakan hubungan sumbang yang artinya adalah hubungan saling mencintai yang bersifat seksual yang dilakukan oleh pasangan yang memiliki ikatan keluarga (kekerabatan) yang dekat, biasanya antara ayah dengan anak perempuannya, ibu dengan anak lakilakinya, atau sesama saudara kandung atau saudara tiri. Pengertian istilah ini lebih bersifat sosioantropologis daripada biologis (bandingkan dengan kerabat-dalam untuk pengertian biologis) meskipun sebagian penjelasannya bersifat biologis. Hubungan sumbang diketahui berpotensi tinggi menghasilkan keturunan yang secara biologis lemah, baik fisik maupun mental (cacat), atau bahkan menyebabkan kematian. Beberapa budaya menoleransi hubungan sumbang untuk kepentingankepentingan tertentu, seperti politik, kemurnian ras atau kepercayaan seperti budaya kembar buncing di Bali yang akan berakhir menjadi inses antarsaudara 
kandung. Peristiwa inses dalam budaya Bali sebenarnya erat kaitannya dengan kebohongan massal yang dilakukan oleh masyarakat setempat. Masyarakat setempat dituntut untuk tidak membocorkan identitas asli sepasang kembar buncing yang nantinya akan dinikahkan. Mereka dipaksa untuk tutup mulut dengan kebohongan besar tersebut. Masyarakat Bali percaya bahwa sepasang buncing adalah jodoh sejak di rahim ibu sehingga harus diabadikan dan tugas merekalah untuk mengabadikan cinta tersebut.

Islam adalah agama yang benar, agama yang memudahkan. Dalam Islam, seorang anak adalah anugerah yang sangat besar. Anak adalah rezeki bagi setiap keluarga dan harus dijaga, disayangi juga diperlakukan dengan baik. Budaya seperti meng-aibkan anak kandung yang jelas itu adalah anugerah dari Allah adalah perbuatan dosa. Islam melarang kejahatan sehingga inses diharamkan oleh Allah. Islam mengharamkan hubungan kekeluargan atau sedarah karena akibat yang ditimbulkan fatal.

Dilihat dari kajian genetik saja, kemungkinan pasangan inses akan menghasilkan keturunan yang lebih banyak membawa gen homozygot. Beberapa penyakit yang diturunkan melalui gen homozygot resesif yang dapat menyebabkan kematian pada bayi yaitu anemia, gangguan penglihatan pada anak umur 4-7 tahun yang bisa berakibat buta, albino, polydactyl, dan sebagainya. Pada perkawinan sepupu yang mengandung gen albino, kemungkinan keturunan albino lebih besar 13,4 kali dibandingkan perkawinan biasa. Kelemahan genetik lebih berpeluang muncul dan riwayat genetik yang buruk akan bertambah dominan serta banyak muncul ketika lahir dari orang tua yang memiliki kedekatan keturunan.

Gangguan emosional yang dialami si ibu akibat kehamilan yang tidak diharapkan akan memengaruhi pertumbuhan dan perkembangan janin sebelum dan sesudah kelahiran. Selain itu, banyak penyakit genetik yang peluang munculnya lebih besar pada anak yang dilahirkan dari kasus inses, seperti kelainan genetik yang menyebabkan gangguan kesehatan jiwa (skizofrenia), keterlambatan mental (idiot), dan perkembangan otak yang lemah (Dirgantara dalam web-kemal.blogspot.com). Oleh karena itu, Islam melarang hubungan antarsedarah karena berakibat fatal bagi bayi yang dilahirkan oleh pasangan itu nantinya. Atas dasar tersebut, penulis tertarik untuk membahas masalah fenomena hukum adat ini dan melandasakan persepsi Islam di dalamnya.

\subsection{Rumusan Masalah}

Berdasarkan latar belakang sebelumnya, masalah yang dibahas dalam makalah ini adalah bagaimana fenomena hukum adat Bali terhadap bayi kembar buncing dalam novel Incest karya I Wayan Artika.

\subsection{Tujuan Penelitian}

Berdasarkan latar belakang dan rumusan masalah, penelitian ini bertujuan untuk memaparkan fenomena adat Bali terhadap bayi kembar buncing dalam novel Incest karya I Wayan Artika.

\subsection{Manfaat Penelitian}

1. Mengetahui bahwa kebudayaan Jelungkap tidak sesuai dengan nilai-nilai moral, nilai-nilai Islam, dan menentang hak asasi manusia.

2. Menyadarkan bahwa Islam adalah agama yang baik dan Allah sudah mengatur segala sesuatunya di dalam Alquran.

\subsection{Metode Penelitian}

Dalam penelitian ini, penulis menggunakan metode kualitatif. Metode penelitian kualitatif adalah metode penelitian yang digunakan untuk meneliti kondisi objek yang alamiah. Peneliti sebagai instrumen kunci. Teknik pengumpulan data secara gabungan; analisis data bersifat induktif dan hasil penelitian kualitatif lebih mementingkan makna daripada generalisasi. Dalam metode kualitatif, pengumpulan data tidak dipandu oleh teori, tetapi dipandu oleh fakta-fakta yang ditemukan saat penelitian. Oleh karena itu, analisis data yang dilakukan bersifat induktif berdasarkan fakta-fakta yang ditemukan dan kemudian dapat dikonstruksikan menjadi hipotesis atau teori. Metode kualitatif digunakan untuk mendapatkan data yang mendalam, suatu data yang mengandung makna. Makna adalah data yang sebenarnya, data yang pasti yang merupakan suatu nilai dibalik data yang tampak. (Sugiyono, 2008) Metode ini lebih mementingkan proses daripada hasil. Berbeda dengan metode kuantitatif, dalam analisis datanya, metode ini tidak menggunakan analisis statistik, tetapi lebih banyak 
secara naratif. Data kualitatif yang digunakan mencakup beberapa hal seperti

a) deskripsi yang mendetail tentang situasi, kegiatan, atau peristiwa ataupun fenomena tertentu;

b) pendapat langsung dari orang-orang yang berpengalaman, pandangannya, kepercayaannya, sikapnya, dan jalan pikirannya;

c) cuplikan dari dokumen, dokumen laporan, arsiparsip, dan sejarahnya; dan

d) deskripsi yang mendetail tentang sikap dan tingkah laku seseorang

Oleh karena itu, agar dapat mengumpulkan data kualitatif dengan baik, peneliti harus tau apa yang harus dicari, asal-muasalnya, dan hubungannya dengan yang lain, yang tidak terlepas dari konteksnya (Yusuf, 2007:53).

\section{KERANGKA TEORI}

\subsection{Pendahuluan}

Dalam menganalisis nilai-nilai budaya yang ada dalam novel Incest, dalam makalah ini, kami lebih memfokuskan pada pendekatan sosiologi-sastra yang lebih melihat hubungan karya sastra dengan masyarakat. Sosiologi sastra lebih mengutamakan penelaahan nilai-nilai yang harus dihayati oleh masyarakat. Dalam perkembangannya, pendekatan sosiologi terhadap sastra terbagi dalam dua jalur utama. Pertama adalah pandangan yang dikenal dengan positifisme, yaitu usaha untuk mencari hubungan antara sastra dengan beberapa faktor, seperti iklim, geografi, ras, dan kebudayaan. Dalam pengertian ini sastra meliputi juga bidang filsafat dan politik. Sastra dianggap sebagai fakta seperti halnya faktor-faktor lain itu dan memiliki status yang sama dalam penelitian ilmiah. Pandangan ini menyatakan bahwa tidak ada ukuran mutlak dalam peniliaian sastra. Penilaian artistik sepenuhnya tergantung pada waktu, tempat, dan fungsinya. Pendekatan sosiologis terhadap sastra dapat dilaksanakan sebaik-baiknya asal kritikus tidak melupakan dua hal, yakni peralatan murni yang dipergunakan pengarang besar untuk menampilkan masalah sosial dalam rekaannya dan sudut pandang pengarang itu sendiri lengkap dengan kesadaran serta tujuannya.

\subsection{Teori Sosiologi Sastra}

Sosiologi adalah telaah yang objektif dan ilmiah tentang manusia dalam masyarakat; telaah tentang lembaga dan proses sosial. Sosiologi mencoba mencari tahu bagaimana masyarakat dimungkinkan, bagaimana berlangsung, dan bagaimana tetap ada. Seperti halnya sosiologi, sastra berurusan dengan manusia dalam masyarakat; usaha manusia untuk menyesuaikan diri dan usahanaya untuk mengubah masyarakat itu. Dalam hal isi, sesungguhnya sosiologi dan sastra berbagi masalah yang sama. Dengan demikian, novel, genre utama sastra utama dalam industri ini, dapat dianggap sebagai usaha untuk menciptakan kembali dunia sosial; hubungan manusia dengan keluarganya, lingkungannya, politik, negara, dan sebagainya. Dalam pengertian dokumen termurni, jelas tampak bahwa novel berurusan dengan tekstur sosial, ekonomi, dan politik-yang juga menjadi urusan sosiologi (Damono, 1984).

Pendekatan sosiologi sastra yang paling banyak dilakukan saat ini menaruh perhatian yang besar terhadap aspek dokumenter sastra. Landasannya adalah gagasan bahwa sastra merupakan cermin zamannya. Pandangan ini beranggapan bahwa sastra merupakan cermin langsung dari pelbagai segi struktur sosial, hubungan kekeluargaan, pertentangan kelas, dan lain lain. Dalam hal ini, tugas sosiologi sastra menghubungkan pengalaman tokoh-tokoh khayal dan situasi ciptaan pengarang itu dengan keadaan sejarah yang merupakan asal-usulnya. Tema dan gaya yang ada dalam karya sastra, yang bersifat pribadi itu, harus diubah menjadi hal-hal yang sosial sifatnya (Damono, 1984).

\subsection{Teori Sastra Cerminan Masyarakat}

Menurut Endraswara (dalam makalah Rokhmansyah, Unnes, 2010), sosiologi sastra adalah penelitian tentang

a. studi ilmiah manusia dan masyarakat secara objektif,

b. studi lembaga-lembaga sosial lewat sastra dan sebaliknya,

c. studi proses sosial, yaitu bagaimana masyarakat bekerja dan bagaimana masyarakat melangsungkan kehidupannya

Menurut Vicomte de Donald (dalam makalah Rokhmansyah, Unnes, 2010), konteks sastra sebagai 
cermin hanya merefleksikan keadaan tertentu pada suatu saat. Istilah cermin ini akan merujuk pada berbagai perubahan dalam masyarakat. Sastra sebagai cermin nilai dan perasaan akan merujuk pada tingkatan perubahan yang terjadi dalam masyarakat yang berbeda dan juga cara individu menyosialisasikan diri melalui struktur sosial.

Karya sastra tidak dapat dipahami secara lengkap apabila dipisahkan dari lingkungan atau kebudayaan atau peradaban yang telah menghasilkannya. Ia harus dipelajari dalam konteks yang seluas-luasnya dan tidak hanya dirinya sendiri karena setiap karya sastra adalah hasil dari pengaruh timbal balik yang rumit dari fakta-fakta sosial dari kultural yang rumit.

Untuk memahami karya sastra secara lengkap, Grebstein (Damono, 1978:4) menyatakan bahwa karya sastra tidak dapat dipahami selengkaplengkapnya apabila dipisahkan dari lingkungan, kebudayaan, atau peradaban yang telah menghasilkannya. Grebstein dalam Damono (1978:4) sebagaimana sosiologi sastra berusaha dengan manusia di masyarakat dalam usaha manusia menyesuaikan diri dan usahanya untuk mengubah masyarakat itu. Dalam hal ini, sesungguhnya sosiologi dan sastra berbagi hal yang sama (Damono, 1978:8). Maka karya sastra perlu dipelajari dalam konteks yang seluas-luasnya. Karya sastra merupakan objek kultural yang rumit atau kompleks dan bagaimanapun karya sastra bukan suatu gejala yang tersendiri.

\subsection{Kebudayaan}

Menurut Koentjaraningrat (dalam Damono, 1978) kata kebudayaan berasal dari bahasa Sansekerta buddhayah, yaitu bentuk jamak dari buddhi yang berarti 'budi atau akal'. Dengan demikian, kebudayaan dapat diartikan sebagai hal-hal yang bersangkutan dengan akal.

Ada ahli lain yang mengupas kata budaya sebagai suatu perkembangan dari majemuk budi-daya, yang berarti daya dari budi. Oleh karena itu, mereka membedakan budaya dan kebudayaan sehingga budaya adalah daya dari budi yang berupa cipta, rasa, dan karsa, sedangkan kebudayaan adalah hasil dari cipta, rasa, dan karsa.

Budaya atau kebudayaan dalam bahasa Belanda diistilahkan dengan cultuur. Dalam bahasa Inggris, kata budaya berasal dari kata culture. Dalam bahasa
Latin kata budaya berasal dari kata colere. Adapun kata culture, yang merupakan kata asing yang sama artinya dengan kebudayaan berasal dari kata Latin colere yang berarti 'mengolah, mengerjakan', terutama mengolah tanah atau bertani. Dalam arti ini, berkembang arti culture sebagai 'segala daya upaya serta tindakan manusia untuk mengolah tanah dan merubah alam'.

Koentjaraningrat (dalam Damono, 1978) berpendapat bahwa ada tujuh unsur kebudayaan yang dapat ditemukan pada semua bangsa di dunia. Ketujuh unsur yang dapat kita sebut sebagai isi pokok dari tiap kebudayaan di dunia itu adalah bahasa, sistem pengetahuan, organisasi sosial, sistem peralatan hidup dan teknologi, sistem mata pencaharian hidup, sistem religi, dan kesenian.

Ketujuh unsur kebudayaan universal itu masingmasing mempunyai wujud fisik, walaupun tidak ada satu wujud fisik untuk keseluruhan dari satu unsur kebudayaan universal. Namun, semua unsur kebudayaan fisik sudah tentu secara khusus terdiri dari benda-benda kebudayaan.

\subsubsection{Kebudayaan Bali}

Kebudayaan Bali sebagai salah satu bagian dari kebudayaan Indonesia sesungguhnya dapat dilihat sebagai hasil dan sekaligus proses penghayatan terhadap nilai-nilai luhur yang telah disepakati bersama sebagai dasar pijakan oleh para pendukungnya. Dengan demikian, kebudayaan Bali pada awalnya adalah landasan perilaku yang khusus dimaksudkan untuk memenuhi kebutuhan masyarakat Bali sendiri. Namun, ketika kebudayaan Bali ditempatkan ke dalam tatanan kebudayaan Indonesia, usaha-usaha untuk mengembangkan kebudayaan harus diarahkan kepada tatanan yang bersifat nasional (Raharjo, 1998: 1).

\subsubsection{Kembar Buncing di Bali}

Hindu tak mengenal istilah lahir salah atau yang biasa disebut masyarakat lokal sebagai manak salah. Dalam tradisi lokal (Bali), pada masa lalu, ibu yang melahirkan kembar buncing (laki-perempuan) bisa bermakna ganda. Jika keluarga raja yang memiliki putra/putri buncing, hal ini berarti berkah atau keberuntungan. Sebaliknya, bagi masyarakat 
kebanyakan hal ini dikatakan bencana atau aib dan lazim karena mereka adalah manak salah.

Sebenarnya tradisi kerajaan itu sudah dihapus dalam sebuah keputusan DPRD Bali pada tahun 1951. Namun, ternyata dalam konteks kehidupan modern sekarang masih ada yang menerapkan seperti yang terjadi di Nusa Lembongan, Nusa Penida, Klungkung. Bali pada masa lampau memang tidak adil terhadap bayi kembar buncing (dua bayi dengan jenis kelamin berbeda). Menurut mitos, jika lahir di lingkungan kerajaan, bayi kembar buncing dianggap berkah yang membawa keberuntungan. Kembar buncing di lingkungan kerajaan dibesarkan secara terpisah. Setelah mencapai dewasa, keduanya akan dipertemukan kembali dan dikawinkan sebagai suami istri.

Dibandingkan dengan anak lainnya, anak kembar buncing ini memiliki tempat yang sangat terhormat di lingkungan kerajaan. Sebaliknya, jika bayi kembar buncing lahir di luar lingkungan kerajaan, kehadiran sang bayi diyakini sebagai aib. Anggapan noda aib dari kembar buncing bersumber dari ajaran raja yang menjelaskan bahwa pasangan bayi kembar tersebut ketika dalam kandungan telah melakukan hubungan seksual sehingga kehadiran kembar buncing dianggap mengganggu keharmonisan desa. Lebih dari itu, desa menjadi tercemar hingga harus dipulihkan melalui sanksi adat yang ditentukan. (Muhammad, dalam network54.com).

Tindakan diskriminasi seperti ini ternyata masih berlangsung di Bali pada masa ini. Sesuai dengan aturan adatnya, bayi kembar harus menanggung sanksi adat berupa pengucilan ke sebuah lokasi sepi yang sangat jauh dari perkotaan atau desa tempat tinggalnya. Masa pengucilan bayi kembar buncing pun berbeda-beda waktunya. Salah satu sumber menyebutkan bahwa orangtua bayi kembar buncing juga harus di keluarkan dari desa selama 42 hari. Selama tenggang waktu itu pula, orangtua bayi tidak dibolehkan beraktivitas, melakukan perjalanan keluar desa, ataupun mencari nafkah. Pengucilan itu sendiri bermaksud untuk dapat membersihkan aib bawaan kembar buncing.

Sebenarnya tradisi manak salah dan kembar buncing sudah sejak dulu dihapuskan oleh pemerintah setempat. "Jangan bersedih. Sekalipun hidupmu tak makmur, kelahiranmu sebagai manusia hendaknya memperbesar hatimu karena betapa sulit memperoleh kesempatan itu kendati terlahi cacat sekalipun. Sebab sungguh utama hakikat menjelma sebagai manusia karena hanya dia yang dapat menolong dirinya sendiri dari lingkaran samsara/reinkarnasi," Bagawan Wharuci, dalam Sarasamuccaya. Kutipan sastra inilah yang mendasari dibuatnya berbagai keputusan penghapusan tradisi manak salah. Salah satunya dengan bantuan politik etis Belanda yang membuat kaum terpelajar di Bali akhirnya membuka mata tentang tradisi ini. Tanggal 12 Juli 1951, DPRD Bali menetapkan keputusan No.10/DPRD/1951 tentang penghapusan adat manak salah. Melalui berbagai pertimbangan, akhirnya ditetapkan keputusankeputusan berikut.

Pasal 1. Setelah berlakunya peraturan ini, masyarakat yang memiliki bayi kembar buncing tidak dianngap bersalah dan tidak boleh dikenakan hukuman apapun.

Pasal 2. Peraturan ini dapat disebut sebagai penghapusan adat manak salah ataupun kembar buncing.

Pasal 3. Peraturan ini berlaku sejak hari diumumkan.

Sejarah manak salah ternyata belum berhenti sampai di sini. Jelas betapa beratnya meruntuhkan mitos. Banyak di antara orang Bali justru tampak belum menginginkan kesadaran pencerahan itu terbit. Nyatanya belum semua orang Bali ingin cerdas. Akses serba tertutup terhadap teks susastra menjadikan orang Bali kebanyakan mudah dibodohbodohi oleh para pemegang kekuasaan politik maupun agama (junkzthi.blogspot.com). Hal ini terbukti dari terulangnya kembali sejarah. Keputusan No.10/DPRD/1951 tentang penghapusan manak salah bukanlah dewa penyelamat. Entah karena tidak ada sosialisasi atau faktor kesengajaan, gema keputusan ini tak sampai ke desa-desa. Pengucilan terhadap manak salah terus berlangsung.

Ternyata orang Bali lebih takut terhadap mitos, ketimbang menaati keputusan politik. Ketakutan hebat terhadap mitos manak salah membuat keputusan No.10/DPRD/1951 tak berarti apa-apa. Pada tahun 1952, belum genap setahun keputusan penghapusan manak salah disahkan, pasangan Wayan Nyadet dan Made Renas dari Banjar Nyuh Kuning, Ubud, melahirkan kembar buncing. Akibat sanksi yang dijatuhkan desa kepadanya pasangan. Kedua anak 
kembar buncing ini meninggal di pengungsian (balipost.com).

Contoh lainnya adalah kepercayaan di Desa Pakraman Padangbulia, Kecamatan Sukasada, Buleleng. Mitos yang telah berurat akar kuat hingga ke sumsum benak masyarakatnya meluruhkan pelarangan lembaga agama bahkan keputusan politik sekalipun. Citra yang dibangun secara kolektif bahwa bayi yang terlahir kembar buncing di Pura Desa harus ditempatkan di lokasi pesucian yang dinamakan Ulun Campuhan (pertemuan dua hulu sungai) selama tiga tilem (bulan mati atau sembilan puluh hari). Bila dilanggar, masyarakat takut terjadi musibah terhadap keluarga si kembar buncing maupun warga sedesa.

Dari berita di atas dapat disimpulkan bahwa usaha pencabutan tradisi kembar buncing sesungguhnya sudah dilakukan. Namun, warga yang mendapat bayi kembar buncing kembali lagi melaksanakan aturan turun-temurun ini karena takut dengan ancaman niskala, yang tak tampak mata. Awig-awig (tradisi atau hukum adat) Desa Pakraman sama sekali sudah tak mengatur sanksi bagi bayi kembar buncing. Hal ini murni keinginan orangtua bayi tersebut. Pengaitan tradisi dengan sesuatu di luar jangkauan nalar yang tak urung membuat tradisi-tradisi tak sejalan dengan perkembangan zaman pun tetap hidup alot dan liat di Bali.

Namun, tak selamanya kembar buncing itu dianggap salah oleh masyarakat Bali. Sedikit angin sejuk pun berembus. Jauh berbeda, bila di Desa Padangbulia, bayi lahir kembar buncing beserta keluarganya harus ditempatkan di luar rumah dalam kurun waktu tertentu. Kelahiran bayi kembar buncing di Banjar Pekandelan, Sukawati, Gianyar tak mesti menempati lokasi khusus, apalagi sampai dijaga warga desa. Mereka juga tidak menggelar upacara khusus setingkat penyucian desa/membersihkan pekarangan rumah. Kelahiran mereka tidak dibedakan dengan anak-anak lain, tak lagi berlaku sanksi manak salah. Sanksi ini telah dihapuskan sejak zaman kolonial Belanda.

Memang sudah seharusnya tradisi ini dihapuskan. Betapa sia-sianya jika tradisi ini tetap dipertahankan, apalagi tak sanggup memuliakan harkat kemanusiaan manusia pendukungnya. Bahkan tradisi ini termasuk bentuk pelanggaran hak asasi manusia bila begitu berat beban orang tua dengan bayi kembar buncing.
Menurut Ratnasari dalam balipost.com, setelah masa pengucilan berakhir, akan diadakan upacara mecaru yang bertujuan untuk menyucikan bayi kembar tersebut. Namun, bukan hanya itu, terkadang orangtua muda bayi kembar buncing harus membayar denda dan rela melepas salah satu bayinya. Bayi kembar itu harus dipisahkan sehingga kelak saat dewasa mereka tak pernah tahu bahwa mereka adalah saudara kandung dan sedarah, sedangkan warga desa diminta oleh peraturan adat untuk merahasiakannya. Yang terjadi selanjutnya adalah ketua adat akan berusaha mengawinkan keduanya menjadi sepasang suami istri karena menurut kepercayaan warga, bayi kembar buncing memang telah dijodohkan sejak dalam rahim.

Mitos aib yang dibawa oleh kembar buncing ini tertuang dalam awig-awig yang jelas-jelas menggambarkan perlakuan tidak adil dan diskriminatif dari raja. Oleh karena itu, mitos seperti ini harus dihapus karena menodai martabat kemanusiaan. Seperti yang kita ketahui, di mana pun di dunia ini, jika suatu hal telah menjadi mitos, untuk memulihkannya bukanlah pekerjaan yang mudah. Butuh pencerahan secara terus-menerus, terutama terhadap ahli waris yang masih mau mempertahankannya.

Jika ditinjau lebih jauh, hukuman pengucilan itu sangat bertentangan dengan ajaran agama Hindu dan juga hak asasi manusia serta sangat bertentangan dengan kesepakatan Sabha II PHDI (Parisadha Hindu Dharma Indonesia) Bali tahun 1971 serta Perda Bali No. 03/2001 yang semuanya berisi imbauan kepada komunitas adat, terutama jajaran prajuru (pengurus desa adat), supaya menyesuaikan tradisi adatnya dengan hukum agama dan hukum positif yang berlaku di Indonesia (Raharjo, 1998).

\section{FENOMENA HUKUM ADAT BALI TERHADAP BAYI KEMBAR BUNCING}

\subsection{Sinopsis}

Jelungkap, sebuah desa di pedalaman Bali yang masih sarat akan adat istiadatnya. Sepasang suami istri, Nyoman Sika dan Ni Ketut Artini yang seharusnya sedang berbahagia karena dikarunia sepasang bayi kembar laki-laki dan perempuan (buncing) justru dirundung duka karena sepasang bayi kembar buncing dianggap aib bagi desa Jelungkap. 
Mereka harus siap menerima sanksi adat yang mengatur tentang kelahiran buncing, yakni pengasingan, upacara malik sumpah (upacara penyucian), dan pemisahan si kembar dari pasangannya. Kemudian jika umur mereka sudah siap untuk dinikahkan sepasang bucing ini harus dinikahkan dengan kembarannya.

Artini sedang bersedih karena dirinya pasti yang akan dituduh sebagai pembawa aib bagi desanya. Padahal bukan dirinyalah yang meminta buncing tersebut lahir dari rahimnya. Belum lagi orang-orang desa yang akan mencari-cari kesalahan keluarga Sika dan Artini pada masa lampau sehingga sekarang mereka dikutuk melahirkan sepasang buncing. Sika mencoba menenangkan Artini dan mengajaknya mensyukuri kelahiran kedua anaknya.

Sanksi adat pertama harus dijalani Sika, Artini, dan kedua bayi buncingnya, yakni diasingkan ke Langking Langkau dan ditempatkan di sebuah gubuk bambu yang dibuat oleh masyarakat setempat untuk ditempati oleh keluarga Sika selama 42 hari pengasingan. Pengasingan tersebut membuat Artini bertambah sedih karena tidak ada satu orang pun yang boleh mengunjungi mereka salama pengasingan itu kecuali kerabat dekatnya.

Sanksi adat yang kedua adalah upacara malik sumpah, upacara yang harus dilakukan oleh keluarga yang melahirkan kembar buncing. Upacara ini dilaksanakan dengan satu pernyataan yang sangat mengejutkan dari Sika saat upacara.

“...Di Jelungkap adat hanyalah cara untuk mencampurkan antara air dan minyak, persalinan dan aib. Masa lalu yang konyol dan malik sumpah ini saya pilih untuk mengajukan satu yang lain, yaitu masa depan.”

Sanksi adat yang terakhir adalah sanksi yang terberat untuk sepasang suami istri ini. Mereka harus memilih salah satu dari kembar buncing untuk diasuh dan membiarkan bayi yang satunya untuk diasuh oleh orang lain. Akhirnya, Sika dan Artini memberi nama anaknya Putu Geo Antara kepada anak laki-lakinya dan Gek Bulan Armani pada anak perempuannya. Antara diserahkan kepada Gus Eka, sahabat Sika untuk diasuh dan diangkat menjadi anak, sedangkan Armani tetap diasuh oleh Sika dan Artini.

Geo dibawa oleh Gus Eka ke Yogyakarta, sedangkan Bulan tetap tinggal di Jelungkap. Tiba saatnya usia mereka sudah cukup untuk masuk ke universitas, Sika bersama Artini dan dua orang anaknya yang lain mengantar Bulan menaiki bus menuju Yogyakarta untuk melanjutkan studinya di Hubungan Internasional UGM. Sementara itu, di Yogyakarta, Geo juga dimasukkan ke universitas yang sama, tetapi mengambil jurusan Antropologi.

Setelah lulus kuliah, Geo yang berlatar belakang pendidikan antropologi kembali ke Jelungkap. Di rumahnya, Geo membuka perpustakaan dan memberi pelajaran tambahan gratis untuk anak-anak setempat, sedangkan Bulan, kembali ke Jelungkap bersama Komang Wiarsa untuk membuat pertanian organik.

Masyarakat Jelungkap masih menyimpan rahasia bahwa Geo dan Bulan adalah sepasang buncing. Orang desa pun semakin resah ketika mengetahui kedekatan mereka. Geo dan Bulan pun saling jatuh cinta hingga akhirnya menikah.

\subsection{Kisah Kembar Buncing di Bali}

Masyarakat Bali memiliki adat istiadat yang terusmenerus dipelihara dan dilaksanakan, salah satunya adalah kembar buncing, tema besar dalam Incest.

“... mengungkapkan peristiwa Incest yang sengaja dipelihara masyarakat adat terhadap kembar buncing. Di sini terungkap bagaimana masyarakat Bali menganggap bahwa kembar sepasang (laki-perempuan) dianggap membawa aib; ayah ibunya didenda; mereka disingkirkan keluar desa,dan diwajibkan upacara demi upacara" (Artika, 2003:8)

“... skenario adat terhadap sepasang buncing, memisahkan, merahasiakan, lalu menikahkan mereka kelak, justru tersimpan niat mengkuduskan cinta. Bukankah orangorang percaya bahwa sepasang buncing adalah sepasang kekasih sejak rahim bunda, dan itu harus dipertahankan sampai mati? Karenanya, ketika buncing lahir didunia, tugas para penyangga adalah untuk membuat cinta itu abadi selamanya" (Artika, 2003:9)

Dari kutipan di atas, dapat diketahui bahwa sebenarnya inses dalam fenomena kembar buncing ini dilakukan masyarakat tanpa mengetahui akibatnya. Semua dilakukan dengan mengatasnamakan adat istiadat yang sudah ada sejak zaman dahulu. Bali yang kala itu masih menggunakan sistem kasta akibat pengaruh budaya Hindu menjadikan kembar buncing sebagai suatu aib bila terjadi pada masyarakat biasa. Lain hal bila terjadi pada kaum bangsawan. Kembar buncing dianggap sebagai suatu anugerah dari dewa 
mereka. Di sini sangat jelas terlihat bagaimana sistem kasta dari agama Hindu masih sangat kuat pengaruhnya di Bali.

Dari kutipan di atas, penulis menyimpulkan bahwa dalam adat kembar buncing di Bali adalah suatu hal yang lumrah dan wajib untuk dilaksanakan demi membuat cinta tersebut abadi. Masyarakat Bali percaya bahwa sepasang buncing dulu nya adalah kekasih di dalam rahim bundanya. Tugas penyanggalah untuk membuat cinta tersebut abadi. Penyangga tersebut diartikan sebagai masyarakat Bali yang notabene beragama Hindu.

Dirujuk dari dokumen sastra tua Bali, sumber lain ini beranggapan bahwa aib dari kembar buncing bersumber dari ajaran raja yang menjelaskan bahwa pasangan bayi kembar tersebut ketika dalam kandungan telah melakukan hubungan seksual sehingga kehadiran kembar buncing dianggap mengganggu keharmonisan desa. Oleh karena itu, orangtua dan bayi buncing harus diasingkan dan harus melakukan upacara yang sangat membebankan keluarga tersebut.

Menurut May (dalam bicarakembar.com) selama tenggang waktu mereka dikucilkan, orangtua bayi tidak dibolehkan beraktivitas, melakukan perjalanan keluar desa, ataupun mencari nafkah. Pengucilan itu sendiri bermaksud untuk dapat membersihkan aib bawaan kembar buncing. Setelah masa pengucilan berakhir, akan diadakan upacara mecaru yang bertujuan untuk menyucikan bayi kembar tersebut. Namun, bukan hanya itu, terkadang orangtua bayi kembar buncing harus membayar denda dan rela melepas salah satu bayinya. Bayi kembar itu harus dipisahkan sehingga kelak saat dewasa mereka tak pernah tahu bahwa mereka adalah saudara kandung dan sedarah, sedangkan warga desa diminta oleh peraturan adat untuk merahasiakannya. Yang terjadi selanjutnya adalah ketua adat akan berusaha mengawinkan keduanya menjadi sepasang suami istri, karena menurut kepercayaan warga, bayi kembar buncing memang telah dijodohkan sejak dalam rahim.

\subsection{Fenomena Hukum Adat Bali Terhadap Bayi Kembar Buncing}

Proses hukum malik sumpah yang digambarkan pada novel ini terbagi menjadi beberapa proses. Proses hukum malik sumpah terbagi menjadi empat fase, yaitu fase pemberitahuan, fase pengasingan, fase upacara, dan terakhir fase pembuangan salah satu bayi buncing.

Fase pertama ialah proses pemberitahuan. Ketika masyarakat mengetahui bahwa di kelompok masyarakat mereka telah lahir kembar buncing, mereka menguhubungi pihak desa untuk memberikan sanksi hukum kelahiran tersebut. Pada novel ini, penulis menggambarkan proses pemberitahuan kepada masyarakat desa melalui kul-kul. Ketika masyarakat mendengar bunyi kul-kul, mereka langsung mengenakan pakaian adat dan segera berangkat menuju Pura Desa. Pura Desa merupakan salah satu bagian dari tiga pura utama di Bali yang dikembangkan oleh Mpu Kuturan (Pendeta Hindu dari Jawa) (Artika, 2003:50).

Fase kedua adalah fase penghukuman. Setelah masyarakat berkumpul di Pura Desa, masyarakat langsung membawa pihak keluarga yang melahirkan bayi buncing ke Pura Desa. Masyarakat desa langsung menyatakan bahwa orangtua kembar buncing harus melakukan proses penyucian bayi buncing selama 42 hari. Nyoman Sika dan Ketut Artini, sebagai orangtua Geo dan Bulan dalam novel ini harus pergi meninggalkan desa dan berangkat menuju Langking Langkau, tempat pembuangan kotoran masyarakat Jelungkap. Mereka hanya diberikan gubuk tempat tinggal seadanya dan tidak boleh mendapat bantuan dari masyarakat.

Sebelum berakhirnya masa pengasingan, masyarakat bersiap mengadakan upacara malik sumpah. Upacara malik sumpah adalah pembersihan desa dari hal-hal negatif. Sehari sebelum proses tersebut, orangtua bayi kembar buncing harus mengeluarkan babi, ayam, dan itik untuk dikorbankan (Artika, 2003:74). Sesajen tersebut diberikan di Pura Desa untuk penyucian tiga pura lain. Acara malik sumpah dilaksanakan di altar. Kegiatan ini terdiri atas kegiatan seni dan perapalan mantra-mantra pencegah bala celaka.

Setelah upacara malik sumpah, kedua orangtua harus memilih salah satu anak untuk diasuh. Dalam novel ini, tokoh Nyoman Sika memilih bayi perempuan (Bulan) dibandingkan bayi laki-laki (Geo) sebagai proses. 
Annisa Aprinandri ... : Fenomena Hukum Adat Bali terhadap Bayi Kembar ...

\subsection{Analasis Sosiologis terhadap Fenomena Hukum Adat Kembar Buncing di Bali}

Bali pada masa lampau memang tidak adil terhadap kembar buncing. Menurut mitos, jika lahir di lingkungan kerajaan, kembar buncing dianggap berkah yang membawa keberuntungan. Kembar buncing di lingkungan kerajaan dibesarkan secara terpisah. Setelah mencapai dewasa, keduanya akan dipertemukan kembali dan dikawinkan sebagai suami istri. Dibandingkan dengan anak lainnya, anak kembar buncing ini memiliki tempat yang sangat terhormat di lingkungan kerajaan. Sebaliknya, jika bayi kembar buncing lahir di luar lingkungan kerajaan, kehadiran bayi diyakini sebagai aib. Jika dirujuk dari dokumen sastra tua Bali, kehadiran kembar buncing dianggap mengganggu keharmonisan desa. Selain itu, desa menjadi tercemar hingga harus dipulihkan melalui sanksi adat yang ditentukan.

Tindakan diskriminasi seperti ini ternyata masih berlangsung di Bali dewasa ini. Sesuai dengan aturan adatnya, bayi kembar buncing harus menanggung sanksi adat berupa pengucilan ke sebuah lokasi sepi yang sangat jauh dari perkotaan atau desa tempat tinggalnya. Masa pengucilan bayi kembar buncing itu harus dijalani selama 105 hari atau tiga bulan kalender Bali. Selama tenggang waktu itu pula, orangtua bayi tidak dibolehkan beraktivitas, melakukan perjalanan keluar desa, atau mencari nafkah. Pengucilan itu dimaksudkan untuk membersihkan aib bawaan kembar buncing.

Setelah masa pengucilan berakhir, diadakan upacara mecaru yang bertujuan untuk menyucikan bayi kembar tersebut. Bukan hanya itu, terkadang orangtua bayi kembar buncing harus membayar denda dan rela melepas salah satu bayinya. Bayi kembar buncing itu harus dipisahkan sehingga kelak saat dewasa mereka tak pernah tahu bahwa mereka adalah saudara kandung dan sedarah, sedangkan warga desa diminta oleh peraturan yang mengikat mereka untuk merahasiakannya. Yang terjadi selanjutnya adalah ketua adat akan berusaha untuk menikahkan keduannya menjadi sepasang suami-istri, karena menurut kepercayaan warga, bayi kembar buncing memang telah dijodohkan sejak dalam rahim.

Mitos aib yang dibawa oleh kembar buncing ini tertuang dalam awig-awig yang jelas menggambarkan perlakuan tidak adil dan diskriminatif dari raja. Mitos seperti itu harus dihapus karena menodai martabat kemanusiaan. Seperti yang kita ketahui, jika suatu hal telah menjadi mitos, untuk memulihkannya bukanlah pekerjaan yang mudah. Butuh pencerahan secara terus-menerus, terutama terhadap ahli waris yang masih mau mempertahankannya.

Lagipula jika ditinjau lebih jauh, hukuman pengucilan itu sangat bertentangan dengan ajaran agama Hindu dan juga hak asasi manusia, juga kesepakatan Sabha II PHDI (Parisadha Hindu Dharma Indonesia) Bali tahun 1971 serta Perda Bali No. 03/2011 yang semuanya berisi imbauan kepada komunitas adat, terutama jajaran prajuru (pengurus desa adat), supaya menyesuaikan tradisi adatnya dengan hukum agama dan hukum positif yang berlaku di Indonesia (Danandjaja, 1980).

\section{PENUTUP}

\subsection{Simpulan}

Bali merupakan salah satu tempat terindah yang memiliki pesonanya tersendiri. Di balik keindahannya, terungkap ketentuan kuno bahwa bagi masyarakat Bali, kelahiran bayi kembar buncing dianggap membawa aib bagi desanya. Orangtua dan sepasang anaknya harus mengalami penderitaan hukuman adat. Prosesi adat, pengucilan, pembuangan, hingga hukuman menikahkan pasangan kembar buncing.

Secara keseluruhan, I Wayan Artika berhasil mengangkat salah satu sisi Bali dalam karyanya. Penulis telah mengungkapkan sisi lain Bali di balik keindahannya, yaitu hukuman adat yang diskriminatif, khususnya bayi kembar buncing dengan sangat tajam. Dalam perspektif sosiologi sastra, penulis juga telah memperlihatkan ketidakadilan adat terhadap bayi kembar buncing dan orangtuanya. Penulis memiliki pandangan negatif terhadap hukuman adat Bali terkait bayi kembar buncing dengan menunjukkan fenomena tersebut secara jelas sebagai faktor sosial.

Dari data yang kami dapatkan dan hasil analisis kami, dapat disimpulkan bahwa inses dalam kembar buncing ini dilakukan masyarakat Bali tanpa mengetahui akibatnya. Semua dilakukan mengatasnamakan adat istiadat yang sudah ada sejak zaman dahulu. Dalam pandangan adat Jelungkap, sanksi untuk kembar buncing di Bali adalah suatu hal yang lumrah dan wajib untuk dilaksanakan. Ada tiga 
tahap hukuman dalam kebudayaan kembar buncing, yakni diisolasi, melakukan upacara malik sumpah, dan pemisahan bayi buncing dari pasangannya. Budaya kembar buncing ini sangat bertentangan dengan hak asasi manusia karena setiap manusia berhak mendapat hak untuk hidup yang sama.

\subsection{Saran}

Berdasarkan hasil penelitian kami, agar penelitian ini menjadi lebih efektif, peneliti menyarankan agar peneliti selanjutnya melakukan observasi langsung di desa yang masih menggunakan kebudayaan bayi kembar buncing tersebut.

\section{DAFTAR PUSTAKA}

Artika, I Wayan. 2003. Incest. Yogyakarta: Interpre Book.

Damono, Sapardi Djoko. 1984. Sosiologi Sastra: Sebuah Pengantar Ringkas. Jakarta: Pusat Pembinaan dan Pengembangan Bahasa Departemen Pendidikan dan Kebudayaan.

Danandjaja, James. 1980. Kebudayaan Petani Desa Trunyan di Bali. Jakarta: Pustaka Jaya.

Dirgantara, Kemal. "Pengertian Incest," dalam web-kemal.blogspot.com/2012/05/pengertian-incest.html diakses pada tanggal 19 Februari 2013.

Endraswara, Suwardi. 2008. Metodologi Penelitian Sastra. Yogyakarta: Media Pressindo.

Hariyanto, Prima. 2010. Kata Berinfiks dalam Kamus Besar Bahasa Indonesia Edisi Ketiga. Depok: Fakultas Ilmu Pengetahuan Budaya Universitas Indonesia.

Julian, Alvian. "Manak Salah: Manak Salah, Kenapa Salah?," dalam junkzthi.blogspot.com/2010/12/manaksalah.html diakses pada tanggal 19 Februari 2013.

Majong, Krisna. dalam http://melayuonline.com diakses pada tanggal 19 Februari 2013.

May, Rachel. "Tradisi Pengucilan Bayi Kembar Buncing,” dalam bicarakembar.com/2010/03/tradisi-pengucilanbayi-kembar-buncing.html diakses pada tanggal 19 Februari 2013.

Muhammad, Dibara. "Menyoal Manak Salah,” dalam www.network54.com/Forum/178267/message/1011744476/Menyoal+"Manak+Salah" diakses pada tanggal 19 Februari 2013.

Mulyono, Hali dan Hari Untung Maulana. 2011. Panduan Penulisan Karya Tulis Ilmiah Dan Dasar-Dasar Penelitian. Cinangka: NFBS.

Raharjo Supratekno, Aris Agus. 1998. Sejarah Kebudayaan Bali. Jakarta: Depdikbud.

Ratnasari, Henny. “Manak Salah yang Salah,” dalam balipost.com/2010/09/manak-salah-yang-salah.html diakses pada tanggal 19 Februari 2013.

Riyanto, Yatim. 2010. Metodelogi Penelitian Pendidikan. Surabaya: SIC.

Rokhmansyah, Alfian. "Unsur-Unsur Kebudayaan dalam Novel,” dalam phianztoy.com/2010/07/unsur-unsurkebudayaan-dalam-novel.html diakses pada tanggal 19 Februari 2013.

Sugiyono. 2008. Memahami Penelitian Kualitatif. Bandung: CV Alfabeta.

Yusuf, A. Muri. 2007. Metodologi Penelitian. Padang: UNP Press. 